Nagy Zsolt:

\title{
A TRUMP-ADMINISZTRÁCIÓ AFGANISZTÁN-POLITIKÁJA
}

DOI: $\underline{10.35926 / \mathrm{HSZ} .2021 .4 .4}$

ÖSSZEFOGLALó: Donald Trump elnökségének Afganisztán-politikája két szakaszra osztható. Az elsőt a 2017 augusztusában bejelentett stratégia határozta meg, amely lényegét illetően a korábbi elnöki ciklusok egyes elemeinek az újracsomagolása volt. A fó hangsúly a katonai erőfeszítés fokozásán volt a tálibok ellenállásának megtörése érdekében. Amikor ez a stratégia nem hozta meg a várt eredményt, 2018 nyarától Washington - hosszú évek után ismét - tárgyalásokba bocsátkozott a tálibokkal, jelentős engedményeket téve korábbi álláspontjához képest. Ez végül 2020 februárjában az Amerikai Egyesült Államok és a tálibok közötti megállapodáshoz vezetett, megnyitva az utat az afgánközi tárgyalásoknak is. A Trump-adminisztráció egy törékeny békefolyamatot és minimálisra csökkentett amerikai jelenlétet hagyott örökségül Afganisztánban. Az amerikai csapatok végleges kivonásáról és a háború befejezéséröl viszont már Trump utóda, Joe Biden döntött.

KULCSSZAVAK: Trump-adminisztráció, Afganisztán-politika, Obama, Amerikai Egyesült Államok, tálibok, afgán kormány, afgánközi béketárgyalások, csapatkivonás, Joe Biden

\section{BEVEZETÉS}

Az Amerikai Egyesült Államok a 2001. szeptember 11. utáni afganisztáni politikájában teljes kört írt le. A tálib rezsim megdöntését követő visszafogott szerepvállalástól a nemzetépítési kísérleteken és a robusztus felkelésellenes müveleten keresztül Donald Trump elnökségének végére Washington minimális katonai jelenléttel a mielőbbi kivonulás lehetőségét és az ahhoz vezető politikai megoldást kereste, majd Joe Biden egyik legelső és nagy horderejü külpolitikai döntéseként bejelentette, hogy 2021. szeptember 11-ig az amerikai csapatok elhagyják Afganisztánt. Az Amerikai Egyesült Államok leghosszabb katonai szerepvállalásának lezárása ezzel kézzelfogható közleségbe került. Mindazonáltal a továbbra is rendkívül instabil afganisztáni biztonsági helyzet, a kabuli kormány gyengesége és a tálibok fokozatos térnyerése jelzik, hogy a tartós béke megteremtése hatalmas kihívás marad a nemzetközi erők távozása után is. A Trump-adminisztráció Afganisztán-politikájának a hagyatéka egy nagyon törékeny békefolyamat volt, amely viszont még így is elmozdulást jelentett a korábbi éveket jellemzö, látszólag célt vesztett amerikai jelenléthez és katonai-müveleti patthelyzethez képest.

Afganisztánban az Amerikai Egyesült Államok 2001 utáni stratégiái legjobb esetben is csak részsikereket hoztak, a hosszabb távú kilátások pedig az évek előrehaladtával egyre kevésbé voltak kedvezőek. A kevés kínálkozó lehetőséget az afganisztáni folyamatok megfordítására az Amerikai Egyesült Államok vagy nem ismerte fel, vagy hibásan mérte fel az 
ahhoz szükséges erőforrásokat. A The Washington Post 2019. decemberi tényfeltáró cikksorozatában mutatta be a korábbi elnöki ciklusok Afganisztán-politikájának ellentmondásait és hibáit. Az egyik legfontosabb következtetése az volt, hogy a beavatkozást követő katonai sikerek után lényegében homály övezte az Amerikai Egyesült Államok Afganisztánnal kapcsolatos további céljait. ${ }^{1}$

Az alábbi írásban Trump elnökségének négy évét tekintjük át, két meghatározó momentumra helyezve a hangsúlyt. Az egyik a 2017-es új afganisztáni stratégia, amely lényegét tekintve a korábbi adminisztrációk által már alkalmazott eszközök újracsomagolása volt. Másodszor, a tálibokkal 2018 nyarán megindult tárgyalások, amelyek a politikai rendezést előtérbe helyezve végső soron új fejezetet nyitottak az ország Afganisztán-politikájában, mégha törékeny és bizonytalan kimenetellel bíró formában is.

\section{ÚT AZ ÚJ STRATÉGIÁIG}

Donald Trump már jóval politikai ambícióinak nyilvánosságra hozatala előtt, magánemberként is számos alkalommal éles kritikával illette Washington szerepvállalását és az elhúzódó amerikai katonai jelenlétet Irakban és Afganisztánban. Különösen a 2011-2013 közötti időszakban nyilvánult meg gyakran a kérdésben Twitter-üzeneteiben. Obamával abban az egyetlen esetben értett egyet, amikor a korábbi elnök csapatlétszám-csökkentésekről döntött. ${ }^{2}$ Az elnökségért folyó 2016-os kampány során a két jelölt, Hillary Clinton és Trump feltünően hallgattak az afganisztáni kérdésről, ami föleg a republikánus elnökaspiráns korábbi harsány kivonuláspárti megnyilvánulásainak tükrében volt meglepő. Trump például egyetlenegyszer említette Afganisztánt a három elnökjelölti vita során, kijelentve, hogy véget kell vetni az ottani „,nemzetépítésnek”. ${ }^{3}$

A 2016-os év fejleményei Afganisztánban mindenesetre nem kecsegtettek túl sok jóval a következő adminisztráció számára. Obama a romló helyzetet látva már 2015 őszén úgy döntött, hogy a csapatcsökkentést felfüggeszti, és a következő év folyamán a tervezett 5500 fö helyett 8400 amerikai katona marad Afganisztánban. ${ }^{4}$ Kabulban a szemben álló felek hiába állapodtak meg a 2014-es vitatott kimenetelü helyi elnökválasztás után, elkeseredett hatalmi harcok folytak Ashraf Ghani elnök és Abdullah Abdullah kvázi kormányfő között. ${ }^{5}$ A tálibok és az Afgán Nemzeti Biztonsági Erők (Afghan National Security Forces - ANSF) fegyveres konfliktusainak száma is exponenciálisan nőtt: 2015-höz képest 2016-ban 22\%-kal több volt a súlyos összecsapások száma január és október között, felülmúlva az igen véresnek számító

\footnotetext{
Craig Whitlock: The Afghanistan papers. The Washington Post, 09. 12. 2019. https://www.washingtonpost.com/ graphics/2019/investigations/afghanistan-papers/afghanistan-war-confidential-documents/ (Letöltés időpontja: 2020. 03. 18.)

2 Jacob Pramuk: What Trump said about Afghanistan before he became president. CNBC, 21. 08. 2017. https://www. cnbc.com/2017/08/21/what-trump-said-about-afghanistan-before-he-became-president.html (Letöltés időpontja: 2020. 09. 15.)

3 Robert Burns - Deb Riechmann: Afghanistan: The war Trump and Clinton have ignored. AP News, 02. 11. 2016. https://apnews.com/article/1cf16a133b02463fa7c796cb53aa826e (Letöltés időpontja: 2020. 09. 18.)

4 Statement by the President on Afghanistan. The White House, 15. 10. 2015. https://obamawhitehouse.archives. gov/the-press-office/2015/10/15/statement-president-afghanistan (Letöltés időpontja: 2020. 08. 25.)

5 Abdullah a 2014-es afganisztáni elnökválasztáson indult jelöltként. A kétfordulós szavazást követően a visszaélések miatt hónapokon keresztül vita tárgya volt az eredmény, végül Washington nyomására megegyezés született közte és Ashraf Ghani között, melynek értelmében az utóbbi lett az új afgán elnök, míg Abdullah miniszterelnöki jogkört kapott az újonnan létrehozott „föigazgatói” (chief executive) pozícióban.
} 
2011-es évet is. ${ }^{6}$ A tálibok a sikereken felbátorodva fokozták a katonai nyomást, és az év végére több terület felett gyakoroltak kontrollt, mint 2001 óta bármikor. A kevés pozitívum között említhetö ugyanakkor, hogy 2016 októberében Brüsszelben Afganisztán-konferenciát tartottak az Európai Unió és az afgán kormány társrendezésében, amelyen a részt vevő 75 ország és 26 nemzetközi szervezet 2020-ig összesen 15,2 milliárd dollárt ajánlott fel az ország fejlesztésére.

Beiktatását követően Trump elnök az afganisztáni és a dél-ázsiai politika átfogó felülvizsgálatára és különböző opciók kidolgozására utasította James Mattis védelmi minisztert és nemzetbiztonsági csapatát. John Nicholson tábornok, az afganisztáni erők parancsnoka időközben februári kongresszusi meghallgatásán fejtette ki meglátásait az afganisztáni helyzetről. Legerősebb megállapítása az volt, mellyel - az általában elvárt győzelmi jelentésekhez képest - az afgán biztonsági helyzetet patthelyzetként jellemezte. Ugyanakkor úgy vélte, hogy 2016 ,,politikai sikereket” hozott az Amerikai Egyesült Államok számára a müveletben, és ahogy - a részletek kifejtése nélkül - összegzett, ,kétségkívül, elsödleges célunkat elérjük Afganisztánban”. Már ekkor elhangzott, hogy további „pár ezer” - nem feltétlenül amerikai - katonára lenne szüksége ahhoz, hogy még hatékonyabb lehessen az afgán biztonsági erők kiképzése?

Még bármilyen új stratégia meghirdetése előtt, 2017 júniusában Trump szabad kezet adott védelmi miniszterének, Mattisnak az afganisztáni katonai létszám meghatározására. A Pentagon korábban több opciót is kidolgozott az amerikai kontingens 3000 és 5000 fö között mozgó létszámnövelésére, de a csapatlétszám meghatározásának delegálása éles váltás volt elődje gyakorlatával szemben, mellyel az ilyen jellegü döntéseket a Fehér Ház saját hatáskörében tartotta. A katonai erő nagyságát övező vitákkal egyidejüleg a várakozás is egyre nőtt az új Afganisztán-politika kialakítására. John McCain, a Szenátus Fegyveres Erők Bizottságának elnöke egyike volt a sürgető hangoknak: ,Bíztam benne, hogy az első 30-60 napban lesz egy stratégia, amellyel el tudunk indulni. Csak annyit mondhatok, ha mi nem kapunk önöktöl stratégiát, majd önök kapnak tölünk.” A védelmi miniszter július közepére ígérte a részletek ismertetését, és ekkor hangzott el az a nagy visszhangot kiváltó megállapítás is Mattistól, mely szerint az Amerikai Egyesült Államok nem áll nyerésre Afganisztánban. ${ }^{8}$

Az új stratégia kidolgozását nem könnyítette meg, hogy Trump és nemzetbiztonsági csapata nézetei igencsak távol estek egymástól. 2017. július 20-án a Pentagonban került sor arra az elnöki tájékoztatóra, amely a későbbiekben a trumpi biztonságpolitika és a katonai felső vezetőkhöz való viszonyának egyik emblematikus eseményévé vált. Mattis és Rex Tillerson külügyminiszter azzal a szándékkal készítették elő részletes beszámolójukat, hogy bemutassák az Amerikai Egyesült Államok globális katonai elkötelezettségeit és műveleti szerepvállalását, valamint azok jelentőségét Washington kapcsolatrendszerében, szövetségesi

6 The situation in Afghanistan and its implications for international peace and security. Report of the UN SecretaryGeneral. A/71/682-S/2016/1049, United Nations Digital Library, 13. 12. 2016. https://digitallibrary.un.org/ record/851672/files/A_71_682\%26S_2016_1049-EN.pdf (Letöltés idöpontja: 2021. 02. 14.)

7 Hearing to Receive Testimony on the Situation in Afghanistan. Stenographic Transcript Before the Committee on Armed Services. United States Senate, Washington D.C., 09. 02. 2017. https://www.armed-services.senate.gov/ imo/media/doc/17-08_02-09-17.pdf (Letöltés időpontja: 2020. 08. 28.)

8 Hearing to Receive Testimony on the Department of Defense Budget Posture in Review of the Defense Authorization Request for Fiscal Year 2018 and the Future Years Defense Program. Stenographic Transcript Before the Committee on Armed Services. United States Senate, Washington D.C., 13. 06. 2017. https://www.armed-services.senate. gov/imo/media/doc/17-58_06-13-17.pdf (Letöltés időpontja: 2020. 09. 18.) 
politikájában. Trump éles hangnemben utasította el az elhangzottakat anélkül, hogy kifejtette volna, milyen alternatív világképben gondolkodik. ${ }^{9}$

\section{A RÉGI-ÚJ STRATÉGIA}

Az elnök és tanácsadói közötti alapvető véleménykülönbség, valamint a fokozódó belpolitikai nyomás közepette az új stratégiát Trump és nemzetbiztonsági csapata végül augusztus 18-án véglegesítette, majd három nappal később a Fort Myer katonai bázison jelentette be az új afganisztáni és dél-ázsiai politikát. ${ }^{10}$ Beszédében Trump elismerte, hogy „,ösztöne szerint" a teljes kivonulás útját választaná Afganisztánban. Az Amerikai Egyesült Államok afganisztáni (és pakisztáni) érdekeit Trump annak megakadályozásában látta, hogy ezek a területek ismét a terroristák búvóhelyeivé váljanak, és hogy a kezükbe nukleáris fegyverek kerüljenek. Az Obama-korszakra utalva aláhúzta, hogy az új politika alappilléreként a „,határidö-központúságot” felváltja a „,feltételalapú” megközelítés, és vége a nemzetépítési kísérleteknek. A politikai megoldás kilátásait illetően Trump óvatos húrokat pengetett: „Egy napon, a hatékony katonai fellépést követöen talán lehetséges lesz egy olyan politikai rendezés, amely magában foglalja az afganisztáni tálib elemeket, de senki nem tudja, hogy ez mikor és egyáltalán bekövetkezik-e.” A tágabb regionális kontextusban keményen üzent az elnök Pakisztánnak, míg Indiával kapcsolatosan stratégiai partnerségről beszélt. Az amerikai katonai jelenlét jövőjét röviden érintve Trump bejelentette, hogy lazít az amerikai katonák alkalmazási korlátozásain, és homályos célzást tett a csapatlétszám növelésére is. Végezetül - az afganisztáni kormánynak címezve - Trump hangsúlyozta, hogy az amerikai elkötelezettség és türelem nem korlátlan, ezért valós eredményeket várnak Kabultól.

Az új stratégia kevés konkrétumot tartalmazott. Az afganisztáni misszió célját és az ahhoz vezető utat Trump nem érintette beszédében, és nem kínált megoldást a nemzetközi jelenlét jövőjére és a polgárháború lezárására vonatkozóan sem. Világossá vált, hogy a katonai eröfeszítés fokozása mögött a politikai rendezés perspektívája másodlagos kérdés, ugyanakkor a szükséges katonai jelenlétre vonatkozóan sem adott semmilyen iránymutatást. ${ }^{11}$ Összességében a bejelentett stratégiával Trump új csomagolásban ugyan, de lényegében visszatért a már korábban mind a Bush, mind a részben Obama által is alkalmazott terrorizmusellenes fellépéshez. A Trump-stratégia leginkább nyers háborús retorikájában tért el a két korábbi elnök Afganisztán-politikájától - nem számítva Obama felkelésellenes müveletét -, semmint a lényegét illetően.

Ugyanakkor még a republikánus táboron belül sem fogadta mindenki pozitívan a bejelentett új politikát. Ezt jelezte, hogy Trump két korábbi elnökaspiráns ellenfele, John Kasich és Rand Paul nyilatkozatokban óvtak az amerikai elköteleződés kiterjesztésétől. A választói bázis elvárásaival szemben elsősorban Mattis és McMaster győzelmeként volt

${ }^{9}$ Carol D. Leonnig - Philip Rucker: 'You're a bunch of dopes and babies': Inside Trump's stunning tirade against generals. The Washington Post, 17. 01. 2020. https://www.washingtonpost.com/politics/youre-a-bunch-of-dopesand-babies-inside-trumps-stunning-tirade-against-generals/2020/01/16/d6dbb8a6-387e-11 ea-bb7b-265f4554af6d_ story.html (Letöltés időpontja: 2020. 09. 25.)

${ }^{10}$ Remarks by President Trump on the Strategy in Afghanistan and South Asia. The White House, 21. 08.2017. https:/www.whitehouse.gov/briefings-statements/remarks-president-trump-strategy-afghanistan-south-asia/ (Letöltés időpontja: 2020. 09. 25.)

11 Wagner Péter: Donald Trump Afganisztán-stratégiájának kérdőjelei. Bátor vállalások vagy üres ígéretek? KKI Elemzések E-2017/20. https://kki.hu/assets/upload/20_KKI-elemzes_USA_Wagner_20171019.pdf (Letöltés időpontja: 2021. 02. 14.) 
értékelhető az új stratégia, amely egyértelmüen ismét a katonai megoldást részesítette elönyben. ${ }^{12}$

A stratégia bejelentését követően nem sokkal Mattis 3500 fős csapatlétszám-növelésről döntött; az új egységek elsődleges feladata a kiképző- és tanácsadói tevékenység támogatása volt. Ezzel együtt azonban nem volt világos, hogy az új politika végrehajtása milyen lépéseken keresztül valósul majd meg a müveleti erőfeszítések fokozásán túl.

\section{KÍSÉRLET A TÁLIBOK VISSZASZORÍTÁSÁRA}

Az új stratégiától és az azt alátámasztani hivatott közel 12 ezer fösre növelt amerikai jelenléttől azt várták Washingtonban, hogy az amerikai erők és a nemzetközi koalíció visszaszerzik a müveleti kezdeményezést, és a katonai nyomás alatt a tálibok engedményekre lesznek hajlandók a politikai rendezés érdekében. Mindkét várakozás hiábavalónak bizonyult, mint az elmúlt másfél évtizedben már oly sokszor.

Már a 2018 tavaszán indított tálib offenzíva előtt is meredeken nőtt a fegyveres összecsapások, a merényletek és a civil áldozatok száma Afganisztánban. A Kabuli Folyamat elnevezésű békekonferencián februárban Ghani ismét ambiciózus békeajánlattal állt elő a tálib lázadók felé, újfent eredménytelenül. Az afgán elnök erőfeszítéseinek annyi eredménye lett csupán, hogy júniusban a kabuli kormánynak sikerült egy háromnapos tủzszünetet kötnie a tálibokkal, a későbbi hasonló ajánlatot az iszlamista szervezet azonban már elutasította. A tálibok augusztusi rajtaütése a Kabultól alig száz kilométerre délre fekvő stratégiai fontosságú Gazni városán, és a közel 300 ezer fős település nagy részének elfoglalása szimbolikus jelentőségű volt. A közel ezer tálib által végrehajtott akcióban az ANSF közel kétszáz főt vesztett, mire hat nap után vissza tudta szerezni az ellenőrzést a város felett.

A 2018. őszi parlamenti választás a tálibok fenyegetései mellett, feszült biztonsági helyzetben zajlott. Legalább tíz parlamenti képviselőt gyilkoltak meg a kampányidőszak alatt, Kandahár tartomány rendőrfőnöke pedig csupán két nappal a voksolás előtt lett merénylet áldozata azon a találkozón, melyre az amerikai erők parancsnoka, Miller tábornok is hivatalos volt (de nem sérült meg). Ilyen körülmények között végül csupán a választásra jogosultak kevesebb mint fele, négymillióan adták le szavazatukat. Az elhúzódó és kaotikus szavazatszámlálási folyamat miatt az eredmények ismertetésére csak hét hónappal a választások után, 2019 májusában került sor.

Ezen körülmények között, több mint egy évvel Trump Afganisztán-stratégiájának bejelentése után lényegében ugyanaz volt a háború állása, mint oly sokszor a korábbi évek során. A patthelyzetben az Amerikai Egyesült Államok nem volt képes a konfliktust döntésre vinni, a tálib felkelés ereje és befolyása nem csökkent, a kabuli kormány pedig gyenge volt ahhoz, hogy az országot akár még a fennhatósága alá tartozó területeken is tartósan stabilizálni tudja. Trump ekkoriban egyre többet kezdett beszélni arról, hogy Afganisztánból ki akar vonulni. ${ }^{13}$ Az elnök növekvő szkepticizmusa mellett fontos fejlemény volt, hogy 2018 tavaszán

12 Julie Hirschfeld Davis - Mark Landler: Trump Outlines New Afghanistan War Strategy With Few Details. The New York Times, 22. 08. 2017. https://www.nytimes.com/2017/08/21/world/asia/afghanistan-troops-trump.html (Letöltés időpontja: 2020. 09. 19.)

13 Michael Scherer et al.: In private chat with senator, Trump hints at policy shift in Afghanistan. The Washington Post, 30. 04. 2018. https://www.washingtonpost.com/politics/in-private-chat-with-senator-trump-hints-at-policyshift-in-afghanistan--and-a-return-to-isolationism/2018/04/30/e0e9b1ec-4995-11e8-827e-190efaf1flee_story.html (Letöltés időpontja: 2020. 08. 26.) 
két kulcspozícióban is változás történt az elnök nemzetbiztonsági csapatában. Tillersont az addigi CIA-igazgató, Pompeo váltotta a külügyminisztérium élén, míg McMaster nemzetbiztonsági tanácsadó helyére a keményvonalas egykori ENSZ-nagykövet, John Bolton érkezett.

Az elnök a Nemzetbiztonsági Tanács 2018. november 8-i ülésen kikelt a helyzetet látva, mint fogalmazott: ,, vereséget mérnek ránk, és (a tálibok) tudják, hogy megvernek bennünket”. Mattis azonban a katonai erőfeszítések folytatása mellett állt ki, szerinte ugyanis voltak felmutatható eredmények. Végül Pompeo győzte meg a türelmetlen elnököt arról, hogy a következő év február 14-ig adjon haladékot a Pentagonnak a kivonulás katonai opcióinak kidolgozására. ${ }^{14}$

A 2018-as év az afganisztáni biztonsági helyzet szempontjából nemcsak nehezen indult, hanem rendkívül negatív mérleggel is zárult. A civil áldozatok száma az ENSZ éves jelentése szerint azóta nem volt olyan magas (10 993 fő), mióta erről statisztikát készítenek, csupán az előző évhez képest 11\%-kal magasabb volt a halálos áldozatok aránya. ${ }^{15} \mathrm{~A}$ kabuli kormány az ország területének kevesebb mint $60 \%$-a felett gyakorolt fennhatóságot, a maradék vagy a tálib felkelök kezén volt, vagy vitatott területnek számított. Ezzel folytatódott az a tendencia, amely a tálibok lassú, de fokozatos vidéki térnyerésével volt jellemezhető. ${ }^{16}$ Az afganisztáni biztonsági erők továbbra sem voltak képesek a rend és a biztonság önálló fenntartására, ráadásul összlétszámuk csökkenő tendenciát mutatott: az elöirányzott 350 ezer főhöz képest csak valamivel több mint 312 ezer katona és rendőr teljesített szolgálatot, ami az egy évvel korábbi számoknál 3\%-kal volt kevesebb. 2012-höz képest közel 30 ezer rendőrrel volt kevesebb az Afgán Nemzeti Rendőrség (Afghan National Police - ANP) kötelékében. ${ }^{17}$

Az afganisztáni katonai erőviszonyok megváltoztatására tett újabb amerikai kísérlet egyre bizonyosabb kudarca és az ezzel járó romló biztonsági helyzet, valamint a washingtoni kormányzaton belül kiélesedő viták előrevetítették, hogy a 2017. augusztusi stratégia módosítására lesz szükség. Hogy a háttérben elkezdődött béketárgyalásoknak az amerikaiak és a tálibok között van-e jövője, az attól függött, hogy képes-e valamelyik fél a korábbi merev feltételrendszertől elmozdulni és érdemi párbeszédbe kezdeni.

\section{A DIPLOMÁCIÁÉ A FÖ SZEREP}

Az „új” stratégia eredménytelenségének egyre nyilvánvalóbbá válásával 2018 derekára lényegében három lehetősége volt a Trump-adminisztrációnak. Először, a rövid időn belüli teljes kivonulás és Afganisztán magára hagyása, az elnök egyre erősödő szándéka szerint. Másodszor, a nagyjából tízezer fős katonai jelenléttel a terrorizmusellenes katonai fellépés folytatása, elkerülve az érdemi erőfeszítéseket a változtatásokra. Végül a diplimáciai erőfeszítések fokozása a tárgyalásos rendezés érdekében, és megállapodás a tálibokkal. ${ }^{18}$

14 John Bolton: The Room Where it Happened. A White House Memoir. Simon\&Schuster, New York, $2020,217$.

15 Afghanistan - Protection of Civilians in Armed Conflict. Annual Report 2018. UNAMA-UNHR, 24. 02. 2019., 1. https://unama.unmissions.org/sites/default/files/afghanistan_protection_of_civilians_annual_report_2018_final_24_ feb_2019_0.pdf(Letöltés időpontja: 2021. 02. 14.)

16 Wagner Péter: Terrorhullám Kabulban. Valóban erősödik a Talibán és az Iszlám Állam Afganisztánban? KKI Elemzések E-2018/06. https://kki.hu/assets/upload/06_KKI-elemzes_AFG_Wagner_20180206.pdf (Letöltés időpontja: 2021. 02. 14.)

17 SIGAR Quarterly Report to the United States Congress. 30. 10. 2018. Special Inspector General for Afghanistan Reconstruction, 30. 10. 2018. https://www.sigar.mil/pdf/quarterlyreports/2018-10-30qr.pdf (Letöltés időpontja: 2021. 02. 14.)

18 Például Laurel E. Miller, az International Crisis Group Ázsia programigazgatójának 2019. 09. 19-i képviselőházi külügyi bizottsági meghallgatásán, amelyben ezeket az opciókat részletesen elemezte. https://docs.house.gov/ meetings/FA/FA00/20190919/109992/HHRG-116-FA00-Wstate-MillerL-20190919.pdf (Letöltés időpontja: 2020. 10. 02.) 
Az első opció, föleg a Trump-adminisztrációt jellemző unilaterális megközelítés következtében, a nemzetközi jelenlét gyors és koordinálatlan összeomlását és nagy valószínüséggel a belső afgán frakcióharcok kiújulását eredményezte volna egy életerős tálib mozgalommal szemben, nagyjából az 1990-es évek polgárháborús időszakához hasonló pályára állítva az országot. A második lehetőség lényegében a status quo fenntartását jelentette volna a patthelyzet további, beláthatatlan idejü elhúzódásával. Az első két opcióval szemben a harmadik volt az egyetlen, amelyik minden nehézsége és esetlegessége ellenére az eröszak csökkenésének reményével kecsegtetett, és végső soron előkészítette a fokozatos csapatlétszám-csökkentést úgy, hogy az méltányos távozásnak tünjön, és ne a ,győzelem vagy vereség” narratívájába szorítsa a nemzetközi erők távozását.

Az Amerikai Egyesült Államok és a tálibok kapcsolata kezdetben nem volt ellenséges. Kabul 1996-os tálib erők általi elfoglalása után az amerikai diplomácia komolyan kacérkodott a mozgalom elismerésének gondolatával - leginkább gazdasági okokból -, de arra végül nem került sor, később pedig az Oszama bin Ladennel együttmüködő tálib rezsim az amerikaiak feketelistájára került. ${ }^{19}$ Az afganisztáni tálib uralom 2001. őszi megdöntése után a fundamentalista mozgalmat a politikai rendezésből kihagyták, hogy az néhány évnyi újjászerveződés után felkelés formájában térjen vissza. Először Obama elnöksége alatt voltak kísérletek a tárgyalásos rendezés lehetőségeinek feltérképezésére. 2009 márciusában a frissen hivatalba lépett elnök - szakítva elődje politikájával - úgy vélte, hogy nyitni kell a tálibok mérsékeltebb szárnya felé. ${ }^{20} \mathrm{~A}$ helyzet azonban még nem volt érett az érdemi előrelépésre, Washington diplomáciai erőfeszítésének kudarcát az érdekelt felek - elsősorban az Amerikai Egyesült Államok és a tálibok, de tágabb értelemben a kabuli kormány és Pakisztán - közötti minimálisan szükséges bizalom hiánya okozta. ${ }^{21}$

A tálib felkelők hozzáállását a tárgyaláshoz jól jellemzi egy 2012-es nyilatkozatuk: „Az afgán emberek és az egész világ tudja, hogy az Egyesült Államok az egyetlen valós független tárgyalópartnere a táliboknak. Az amerikaiak a kezdetektöl fogva csak eszközként használták a Karzai-kormányt a megszállásuk meghosszabbitására. Így felesleges párbeszédet folytatni egy olyan kormányzattal, amelyet az amerikaiak neveztek ki, akik egyelöre mindent a kezükben tartanak Afganisztánban. Értelmetlen közvetlen vagy közvetett tárgyalást folytatni az afgán kormánnyal, az csak időpocsékolás lenne.”22

2018 nyarán a tárgyalások újbóli napirendre tủzését végül két tényező tette lehetővé. Egyrészt, a korábban említett júniusi rövid tűzszünet során a szemben álló felek tömeges frontbarátkozására került sor, ami az afgánközi szolidaritás feléledését eredményezte. Másrészt - és az eseményekre nyilvánvalóan ez bírt döntő jelleggel -, változás állt be az amerikai politikában. Washington nem ragaszkodott többé ahhoz az álláspontjához, miszerint a táliboknak először a kabuli kormánnyal kell tárgyalniuk, és késznek mutatkozott a fundamentalista mozgalommal való közvetlen párbeszédre. A Trump-kormányzat új politikája jelentős elmozdulás volt a korábbi évek alapállásához képest, és lényegében a 2017-es

19 Wagner Péter: A tálibok is fundamentalisták, de nem olyan Amerika-ellenes éllel, mint Irán - inkább a szaúdiakhoz állnak közel. KKI Elemzések, E-2020/52. https://kki.hu/wp-content/uploads/2020/05/52_KKI-elemzes_AFG_Wagner_ 20200527.pdf (Letöltés időpontja: 2021. 02. 14.)

${ }^{20}$ Helen Cooper - Sheryl Gay Stolberg: Obama Ponders Outreach to Elements of Taliban. The New York Times, 07. 03. 2009. https://www.nytimes.com/2009/03/08/us/politics/08obama.html (Letöltés időpontja: 2020. 10. 02.)

${ }^{21}$ Wagner Péter: Az Egyesült Államok és Afganisztán kapcsolata a hidegháború után. In: Háda Béla - Matura Tamás (szerk.): Az Amerikai Egyesült Államok ázsiai kapcsolatai. Dialóg Campus, Budapest, 2020, 279-281.

${ }^{22}$ Alex Strick van Linschoten - Felix Kuehn (eds.): The Taliban Reader. War, Islam and Politics. Hurst and Company, London, 2018, 405. 
stratégia eredménytelenségének beismeréseként is értelmezhetö. ${ }^{23}$ Ezzel teljesült a tálibok régi törekvése, hogy közvetlenül tárgyaljanak az amerikaiakkal. A másik oldalon viszont a Ghani-kormányzat az amerikai-tálib kapcsolatfelvételt és a majdani tárgyalásokat érthető gyanakvással követte, tartva a feje fölött meghozott döntések következményeitől. ${ }^{24}$

A diplomáciai front erősítésének fontos eleme volt az amerikai fötárgyaló személyének a kiválasztása. Zalmay Khalilzadot, az afgán származású veterán diplomatát Pompeo 2018 szeptemberében nevezte ki az „afgán megbékélés különmegbízottjának”. Khalilzad korábban a Bush-adminisztráció alatt afganisztáni, majd iraki nagykövetként, később az amerikai ENSZképviselet vezetőjeként is kulcsfigurája volt Washington Afganisztán-politikája alakításának.

Az első biztató jelek a tárgyalások érdemi elörehaladtáról 2019 elején érkeztek. Az amerikai és a tálib delegációk januári katari találkozóján Washington beleegyezett, hogy egyrészt a csapatkivonás nagybani menetrendjét a megállapodás részeként kezeli, másrészt a tálibok elviekben elfogadták azt az amerikai feltételt, hogy nem nyújtanak többé sem támogatást, sem menedéket ahhoz, hogy Afganisztán szélsőséges csoportok tevékenységének kiindulópontja legyen. Ugyanakkor két, az Amerikai Egyesült Államok számára fontos kérdésben nem történt elörelépés, így a tüzszünet és a kabuli kormánnyal való közvetlen tárgyalás ügyeiben.

Minden nehézség ellenére 2019. augusztus végére a hírek már arról szóltak, hogy a megállapodás szövegtervezete lényegében elkészült. Vélhetően a pozitív fejlemények hevületében,Trump és nemzetbiztonsági csapata augusztus 30-i megbeszélésén az elnök váratlanul bejelentette, hogy az Amerikai Egyesült Államok és a tálibok közötti megállapodást Camp Davidben akarja aláírni. ${ }^{25}$ A küszöbönálló megegyezéssel szemben ugyanakkor komoly fenntartások is megfogalmazódtak. A legfóbb félelem az volt, hogy az amerikaiak úgy vonják ki csapataikat, hogy az afgánközi béke még nem valósult meg. John Bolton nemzetbiztonsági tanácsadó is ezt a nézetet vallotta, szerinte a tálibok megbízhatatlanok, velük nem lehet és nem is szabad békét kötni. Bolton úgy vélte, hogy hiba a teljes csapatkivonás Afganisztánból. Ellenállása és különvéleménye oda vezetett, hogy Boltont - példátlan módon - gyakorlatilag kihagyták a megállapodás előkészítésének folyamatából. ${ }^{26}$ Hasonló megfontolások alapján - bár a teljes csapatkivonást nem ellenezve - szólalt fel a tervezett megállapodás ellen kilenc volt korábbi afganisztáni nagykövet, akik szerint az elkapkodott kivonulás „totális polgárháborúba” taszíthatja az országot, teret adva a tálibok mellett az Iszlám Állam megerősödésének is. Javaslatuk az volt, hogy nagyobb mértékű csapakivonásra csak a békemegállapodást követően kerüljön sor, és addig is az Amerikai Egyesült Államok megfelelö terrorizmusellenes erőt tartson Afganisztánban. ${ }^{27}$

${ }^{23}$ Mujib Mashal - Eric Schmitt: White House Orders Direct Taliban Talks to Jump-Start Afghan Negotiations. The New York Times, 15. 07. 2018. https:/www.nytimes.com/2018/07/15/world/asia/afghanistan-taliban-directnegotiations.html (Letöltés időpontja: 2020. 09. 20.)

${ }^{24}$ Secunder Kermani: Afghanistan: Where the road to peace is harder than war. BBC News, 23. 12. 2019. https:// www.bbc.com/news/world-asia-50826420 (Letöltés időpontja: 2020. 09. 20.)

${ }^{25}$ Bolton: i. m. 439.

${ }^{26}$ John Hudson - Josh Dawsey: Bolton sidelined from Afghanistan policy as his standing with Trump falters. The Washington Post, 30. 08. 2019. https://www.washingtonpost.com/world/national-security/bolton-sidelined-fromafghanistan-policy-as-his-standing-with-trump-falters/2019/08/30/79651256-8888-483b-9fd1-c47a2cfadab7_story. html (Letöltés időpontja: 2020. 09. 05.)

27 James Dobbins et al.: US-Taliban negotiations: How to avoid rushing to failure. Atlantic Council, 03. 09. 2019. https://www.atlanticcouncil.org/blogs/new-atlanticist/us-taliban-negotiations-how-to-avoid-rushing-to-failure/ (Letöltés időpontja: 2020. 09. 05.) 
Mindezen előzmények után bombaként robbant Trump szeptember 8-i tweetje, amelyben a Camp Davidbe tervezett, de addig titokban tartott találkozó lemondásáról és a békemegállapodástól való elállásról írt. Döntésének közvetlen indokaként az amerikai katonai áldozattal is járó, összesen tizenkét emberéletet követelő kabuli merényletet jelölte meg. Nagyobb befolyással lehetett azonban Trump váratlan húzására a tervezettel szembeni ellenkezés, különösen az, ami befolyásos republikánus körökből érkezett. ${ }^{28} \mathrm{~A}$ tálibok a maguk részéről mindenesetre készségüket fejezték ki a tárgyalások újrakezdésére, amennyiben Washington megváltoztatja véleményét. ${ }^{29}$

Az amerikai-tálib tárgyalásokkal párhuzamosan egy másik békefolyamat is elindult, amely jól jellemezte Oroszország sajátos szerepét az afganisztáni konfliktusban. Az úgynevezett „moszkvai folyamat” keretében Oroszország kísérletet tett arra, hogy befolyást gyakoroljon az afganisztáni eseményekre. A 2018 novemberében, majd a következő év februárjában Moszkvában tartott találkozókon a tálibok és az afgán ellenzék egyes szereplői egyeztettek egymással, de a találkozókra sem a hivatalban lévő kabuli kormány, sem az amerikaiak - vagyis az afganisztáni rendezés kulcsszereplöi - nem kaptak meghívást. Míg a moszkvai folyamat csak mellékvágánya volt az afganisztáni béke-erőfeszítéseknek, egyfelől demonstrálta Oroszország érdekeltségét az afganisztáni rendezésben, másfelől diplomáciai sikerként volt elkönyvelhető, mint a tálibok és más (nem kormányzati) afganisztáni politikai erők közötti, 2001 óta legjelentősebb kapcsolatfelvétel tető alá hozása.

Az amerikai-tálib tárgyalások elakadásával szinte egy időben tartott, 2019. szeptember 28-i afganisztáni elnökválasztás tétje a politikai rendezés kimenetele szempontjából is nagy volt. A két fő jelölt a 2014-es választásokon már egymással szemben megmérettetett Ashraf Ghani és Abdullah Abdullah voltak, akik azóta is egyfajta hatalommegosztásban, de folyamatos belső konfliktusok közepette irányították Afganisztánt. A korábbi elnökválasztások tapasztalataiból kiindulva és a béketárgyalási folyamat törékenysége miatt Washingtonban felmerült az a gondolat, hogy választások helyett a helyzetnek jobban megfelelne egy átmeneti afgán kormány megalakítása. Az elképzelés támogatói szerint egy elhúzódó elnökválasztási procedúra - különösen akkor, ha második fordulóra is szükség lenne - komolyan késleltetné a béketárgyalásokat. Rosszabb esetben az is előfordulhatna, hogy az új afgán kormány nem hajlandó tárgyalásra a tálibokkal és a szükséges alkotmányos változtatások végrehajtására sem. Ezt az átmeneti kormányra vonatkozó elgondolást vázolta fel egy korábbi, nagy visszhangot kiváltó, átfogó és konkrét pontokba szedett megállapodástervezet is, amelyet „az Amerikai Egyesült Államok egy szövetségese” rendelt meg a RAND vállalattól. A szövegtervezet egyik föbb javaslata szerint egy átmeneti kormányt kellene alakítani tálib képviselök bevonásával az átmenet 18 hónapos időszakára azzal a céllal, hogy előkészítse az új alkotmányt és az új választásokat. ${ }^{30}$ Az átmeneti kormány ellenzői szerint azonban már azért is hosszú politikai harc indulna, hogy abban ki és milyen pozícióban vegyen részt, így gyakorlatilag semmilyen elönyt nem jelentene a választások megtartásához képest. ${ }^{31}$ Ashraf Gahni - aki

${ }^{28}$ Lindsey Graham - Jack Keane: We can't outsource our security to anyone - especially the Taliban. The Washington Post, 28. 08. 2019. https://www.washingtonpost.com/opinions/2019/08/28/afghan-war-must-end-our-terms-nottalibans/ (Letöltés időpontja: 2020. 09. 01.)

${ }^{29}$ Afghanistan war: Taliban tell Trump their „doors are open”. BBC News, 17. 09. 2019. https://www.bbc.com/ news/world-asia-49729612 (Letöltés időpontja: 2020. 09. 05.)

${ }^{30}$ Laurel E. Miller - Jonathan S. Blake: Envisioning a Comprehensive Peace Agreement for Afghanistan. RAND Corporation, 2019. https://www.rand.org/content/dam/rand/pubs/research_reports/RR2900/RR2937/RAND_RR2937. pdf (Letöltés időpontja: 2021. 02. 14.)

31 Dobbins et al.: i. m. 
újbóli megmérettetésre és hivatalának folytatására készült - természetesen szintén hevesen ellenezte az elképzelést. ${ }^{32}$

Ilyen előzmények után a tálibok általi fenyegetés és kölcsönös korrupciós vádaskodások közepette megtartott szavazás alacsony részvétel mellett zajlott. A választási eredmény kihirdetésére eredetileg október 19-én került volna sor, de végül csak a Washington és a tálibok közötti tárgyalások felgyorsulásával egyidejüleg, 2020. február 18-án ismertette az afgán Független Választási Iroda a végleges eredményt. Eszerint Ghani a szavazatok 50,64\%-át, Abdullah pedig a 39,52\%-át kapta meg. Abdullah nem ismerte el a választási eredményt, és párhuzamos kormány felállítását helyezte kilátásba. Az Amerikai Egyesült Államok tárgyalásos rendezési stratégiáját nagymértékben gyengítette egy ismételten kaotikus választás és az azt követő kabuli hatalmi harc. A tálibokkal folytatandó tárgyalások mellett ezért a másik fontos feladat a kabuli kormányzati sorok rendezése volt.

\section{MEGÁLLAPODÁS AZ AMERIKAI EGYESÜLT ÁLLAMOK ÉS A TÁLIBOK KÖZÖTT}

Washington 2019 végén élesztette újra az egyeztetéseket a tálibokkal. A megtorpanásokkal, kölcsönös bizalmatlansággal és bizonytalanságokkal teli másfél éves tárgyalássorozat eredményeképpen a két fél közötti békemegállapodást végül 2020. február 29-én írta alá Dohában Zilmay Khalilzad és Abdul Ghani Baradar molla. ${ }^{33}$ Az egyezség négy, egymással összefüggő elemet tartalmazott: a) az arra vonatkozó kitételeket, hogy Afganisztán többé nem lehet az Amerikai Egyesült Államok és szövetségesei elleni támadás kiindulópontja; b) az Amerikai Egyesült Államok és szövetségeseinek kivonulási tervét; c) az afgánközi tárgyalások elkezdését; d) végleges és átfogó tüzszünet szükségességét Afganisztánban, amely bejelentésekor kiegészül majd egy politikai útitervvel. Maga a február 29-i megállapodás az első két elem tekintetében fogalmazott meg konkrétumokat, amelyek egyben előfeltételei is a másik két területen történő elörehaladásnak.

A legfontosabb rendelkezések értelmében Washington és szövetségesei kötelezettséget vállaltak arra, hogy az aláírás időpontjától számított 14 hónapon belül (azaz 2021. április végéig) kivonják összes katonájukat és civil alkalmazottjukat. Ennek első ütemeként 135 napon belül az amerikai erők létszáma 8600 före csökken majd, míg a koalíciós csapatok is (konkrét számok nélkül) arányosan csökkentik jelenlétüket. Az Amerikai Egyesült Államok arra is kötelezettséget vállalt, hogy közbenjár minden félnél (értsd: az afgán kormánynál) a fogolycseréről történő megállapodás tető alá hozása érdekében. A fogolycserének március 10-ig, az afgánközi tárgyalások megkezdéséig meg kell történnie. A tálibok arra vállaltak kötelezettséget, hogy nem fogják saját tagjaiknak vagy egyéb csoportoknak - beleértve és nevesítve az al-Kaidát - engedni, hogy Afganisztán területét az Amerikai Egyesült Államok és szövetségesei biztonságának fenyegetésére használják.

${ }^{32}$ Mujib Mashal: U.S. and Taliban Agree in Principle to Peace Framework, Envoy Says. The New York Times, 28. 01. 2019. https://www.nytimes.com/2019/01/28/world/asia/taliban-peace-deal-afghanistan.html (Letöltés időpontja: 2020. 09. 06.)

33 Agreement for Bringing Peace to Afghanistan between the Islamic Emirate of Afghanistan which is not recognized by the United States as a state and is known as the Taliban and the United States of America. 29. 02. 2020. https:// www.state.gov/wp-content/uploads/2020/02/Agreement-For-Bringing-Peace-to-Afghanistan-02.29.20.pdf(Letöltés idöpontja: 2020. 09. 07.) 
Sajtóértesülések szerint a nyilvánosságra hozott szövegnek titkos záradékai is voltak, melyekkel kapcsolatosan még közvetlenül a megállapodás aláírása előtt komoly fenntartásának adott hangot 22 republikánus képviselő. ${ }^{34}$ A Pentagon később elismerte a minősített függelékek létét, melyek a csapatkivonás feltételeiről rendelkeznek. ${ }^{35}$

Az amerikai védelmi miniszter, Mark Esper és Jens Stoltenberg NATO-fötitkár a megállapodás időpontjában Kabulban igyekeztek megnyugtatni az afgán kormányt, hogy a jelenlétük nélkül letárgyalt és aláírt megállapodás nem húzza ki a szőnyeget alóla. Ennek alátámasztására Esper és Ghani elnök közös nyilatkozatot adtak ki, melyben a tálibokkal kötött megállapodáshoz hasonlóan megerősítették az afganisztáni és a regionális megbékélés és biztonság elveit. ${ }^{36}$

Hogyan értékelhető a tálibokkal kötött megállapodás? Mindenekelőtt alá kell húzni, hogy az aláírt dokumentum még nem a végső békemegállapodás, de az ahhoz vezető fontos lépés lehet. A tálibok kevés engedményt tettek korábbi elveik feladása terén, míg megkapták az ígéretet a legfontosabb követelésükre, az amerikai csapatok - igaz feltételes, de - határidőhöz kötött távozására. Washington ugyanakkor több kérdésben is engedett korábbi álláspontjából, többek között azzal, hogy az afgán kormányt kihagyták a tárgyalásokból. Abban is bizonyosan jól kalkulált, hogy rugalmasabb politikára volt szükség a tálib felkelők tárgyalóasztalhoz ültetéséhez. Az Amerikai Egyesült Államoknak úgy kellett egyensúlyoznia a tálibokkal folytatott tárgyalás és a kabuli kormányzattal való kapcsolat fenntartása között, hogy közben két stratégiai céljához is közelebb kerüljön, nevezetesen az afganisztáni politikai rendezés előkészítéséhez és katonáinak kivonásához. A február 29-i megállapodás e tekintetben biztató és szükséges, de önmagában még elégtelen lépés volt.

\section{MEGÁLLAPODÁS UTÁN AZ AMERIKAI ELNÖKVÁLASZTÁS ÁRNYÉKÁBAN}

A békemegállapodást követő hónapokban az amerikai katonai jelenlét kérdése állt a viták középpontjában. Az amerikai elnökválasztáshoz közeledve a kérdés még jobban átpolitizálódott, ahogy Trump igyekezett a maga számára pozitív kampánytémává tenni a külföldön állomásozó amerikai erők kivonását. 2020 júniusában Washington 8600 före csökkentette az Afganisztánban állomásozó katonái létszámát, még összhangban a békemegállapodás rendelkezéseivel. A következő hónapokban azonban a csapatkivonás kérdése már önálló életre kelt, az afganisztáni valós helyzet és a politikai rendezés egyre kevesebb figyelmet kapott. Ez a leegyszerüsödött washingtoni diskurzus a kabuli kormány tárgyalási pozíciójának nagymértékü gyengülésével fenyegetett, és az amerikaiak szövetségesei számára is nehezen tervezhetővé tette a NATO kiképző és támogató missziója jövőjét. De mindezen felül az amerikai csapatok létszámát illető bárminemü döntések már nagymértékben befolyásolták a következő elnöki adminisztráció mozgásterét.

${ }^{34}$ Rebecca Kheel: Cheney, House Republicans express 'serious concerns' with US-Taliban deal. The Hill, 27.02. 2020. https://thehill.com/policy/defense/484964-cheney-house-republicans-express-serious-concerns-with-ustaliban-deal (Letöltés időpontja: 2020. 09. 06.)

35 Thomas Gibbons-Neff: US Announces Troop Withdrawal in Afghanistan as Respite From Violence Ends. The New York Times, 02. 03. 2020. https://www.nytimes.com/2020/03/02/world/asia/us-troop-withdrawal-afghanistan.html (Letöltés idöpontja: 2020. 09. 05.)

36 Joint Declaration between the Islamic Republic of Afghanistan and the United States of America for Bringing Peace to Afghanistan. 29. 02. 2020. https://www.state.gov/wp-content/uploads/2020/02/02.29.20-US-AfghanistanJoint-Declaration.pdf (Letöltés időpontja: 2020. 09. 07.) 
Az újabb mandátumért kampányoló Trump kihívója az Afganisztánnal kapcsolatos kihívások alapos ismerője, a demokraták veterán külpolitikusa, Joe Biden volt. A korábbi alelnök ellenezte Obama 2008-2009-es nagyarányú afganisztáni létszámnövelését, és meggyőződéséhez hünek maradva, a későbbiekben is kiállt az amerikai jelenlét lehető legkisebb szükséges szinten tartása mellett. Jóllehet az elnökválasztási kampányban Afganisztán nem volt központi téma, Biden nézetei ismertek voltak ebben a kérdésben. ${ }^{37}$

A 2020. november 3-i rekordrészvételü amerikai elnökválasztás Joe Biden győzelmét hozta. Trump a választások elvesztése után egy héttel menesztette védelmi miniszterét, Mark Espert. Egyes hírek szerint az utolsó cseppet Trump számára az jelentette, hogy Esper nem értett vele egyet a további gyors ütemü afganisztáni kivonulással kapcsolatban, és ezt egy Fehér Háznak címzett november eleji titkosított feljegyzésében bővebben ki is fejtette. ${ }^{38}$ Ezt a narratívát valószínüsíti, hogy november 17-én Christopher Miller, a Trump által frissen kinevezett ügyvezető védelmi miniszter bejelentette, hogy 2021. január 15-ig 2000 fövel csökkentik az amerikai jelenlétet, ezzel minimális, mintegy 2500 före redukálva az afganisztáni csapatlétszámot. Az indoklás szerint a döntés az elnök ígéretének megfelelően azt a célt szolgálja, hogy az amerikai csapatok kivonuljanak az „örökké tartó háborúkból”. A döntés a republikánus táboron belül is heves kritikákat váltott ki. A Szenátus többségi csoportjának republikánus vezetője, Mitch McConnell szerint az elhamarkodott afganisztáni kivonulás következménye „,Amerika 1975-ös megalázó saigoni távozásához lenne fogható” 39 De nem volt pozitív a bejelentés fogadtatása a NATO-szövetségesek körében sem. A Szövetség fötitkára, Jens Stoltenberg arra figyelmeztetett, hogy túl magas ára lehet a korai és koordinálatlan visszavonulásnak.

\section{AZ AFGÁNKÖZI TÁRGYALÁSOK - A TARTÓS RENDEZÉS KULCSA}

Az Amerikai Egyesült Államok és a tálibok által aláírt 2020. februári békemegállapodás értelmében a tárgyalásoknak az afgán kormány és a tálibok között 2020. március 10-én kellett volna elkezdődniük. Hogy ez akkor nem történt meg, az a felszínen a tálib foglyok szabadon engedése körüli eredménytelen vitának volt köszönhető, de valójában a tárgyalóasztalnál aprópénzre váltható minél előnyösebb alkupozíció kivívása volt mindkét fél célja. A tárgyalás egyik szereplője a népszerütlen, területi fennhatóságában korlátozott, a tálibokkal folytatott addigi tárgyalásokról kizárt és a nemzetközi jelenléttől függő kabuli kormány volt, amely egy zavaros és elhúzódó elnökválasztás után belső megosztottságoktól volt terhes. A másik oldalon viszont egy éppen a legnagyobb politikai sikerét learató, sokévi ellenállásban edzett tálib mozgalom volt, amely - úgy tünt - karnyújtásnyira volt sokéves háborús céljának elérésétől, az amerikai erők kivonásától. A nagyon eltérő induló pozíciók és erőviszonyok ellenére egyik fél sem lehetett biztos abban, hogy az ügye győzelemre áll. A tálibok számára elsősorban az amerikai katonai erő és a mögötte álló politikai elkötele-

37 Joseph R. Biden, Jr.: Why America Must Lead Again. Rescuing U.S. Foreign Policy After Trump. Foreign Affairs, 03/04. 2020. https://www.foreignaffairs.com/articles/united-states/2020-01-23/why-america-must-lead-again (Letöltés időpontja: 2021. 02. 14.)

${ }^{38}$ Barbara Starr et al.: Trump fires Secretary of Defense Mark Esper. CNN, 09. 11. 2020. https://edition.cnn. com/2020/11/09/politics/trump-fires-esper/index.html (Letöltés időpontja: 2020. 11. 20.)

39 James Hohmann: The Daily 202: Trump allies more outraged than Democrats over his Afghanistan pullout. The Washington Post, 18. 11. 2020. https://www.washingtonpost.com/politics/2020/11/18/daily-202-trump-alliesmore-outraged-than-democrats-over-his-afghanistan-pullout/ (Letöltés időpontja: 2020. 12. 01.) 
zettség volt a legnagyobb bizonytalansági tényező, míg a kabuli kormány esetében éppen ellenkezőleg, Washington támogatása és katonai jelenléte volt a legfontosabb garanciája a tárgyalási pozíciójának.

Mint láttuk, a kabuli belpolitikai helyzet messzemenő kihatással bírt az afgánközi tárgyalások esélyeire. A tálibok számára kevesebb dolog volt kedvezőbb, mint egy megosztott, politikai belháborúban lekötött kormány, amelyen így is rajta van az amerikai nyomás a lázadókkal való tárgyalások folytatására. Ezért bírt nagy jelentőséggel, hogy 2020. május 17én, hosszú hónapok vitájára pontot téve, Ghani elnök és riválisa, Abdullah között 2014 után újabb hatalommegosztási megállapodás született. Abdullah a Nemzeti Megbékélés Magas Tanácsának az elnöke lett, amely testület majd - elvileg - a végső szó jogával bír a megállapodás megköthetőségéről a tálibokkal folytatandó tárgyalások befejezése után.

A kabuli kormányzati sorok rendezése után is nehezen haladt elöre a közvetlen tárgyalások megkezdésének előkészítése; a folyamatban nagyobb elörelépést jelentett ugyanakkor, hogy augusztusra befejeződött az ötezer tálib fogoly szabadon engedése. A tálibok viszonzásképpen július végén háromnapos tủzszünetet hirdettek, ami csupán a harmadik tüzszünet volt a háború 2001-es kirobbanása óta.

A tálib felkelők azonban a fegyverek átmeneti elhallgatása után ismét visszatértek a kormányzati célpontok intenzív támadásához: nyilvánvaló volt, hogy az erőszakról mint a céljaik eléréséhez szükséges eszközről a tálibok nem voltak hajlandók lemondani. Bár a februári békemegállapodást követően az amerikai és a tálib erők kerülték a közvetlen fegyveres összecsapásokat, az augusztusig eltelt időben az amerikaiak, nyomást gyakorlandó a szélsőséges mozgalomra, legalább tucatszor bombázták a tálib állásokat. A Pentagon a támadásokat nem ismerte el, és a táliboknak sem állt érdekükben aktívan kommunikálni ezeket.

Végül a szimbolikus évfordulón, a szeptember 11-i terrortámadás tizenkilencedik évfordulóján gyültek össze az afgán kormány és a tálibok delegáltjai Dohában, hogy másnap, 2020. szeptember 12-én megkezdjék tárgyalásaikat azzal a céllal, hogy előkészítsék az afgán politikai átmenetet és az új alkotmányt. Az afgán kormány delegációját, mely ellenzéki politikusokat is magában foglalt, Abdullah Abdullah, a Nemzeti Megbékélés Magas Tanácsának első embere vezette, a másik oldalon a tálib tárgyalófelet Mawlawi Abdul Hakim Haqqani fötárgyaló irányította.

Az afgánközi tárgyalások kapcsán a szkeptikusabb hangok gyakran kétségeiket fejezik ki amiatt, hogy a tálibok elképzelése a tartós rendezésről mennyire lehet kompatibilis a többi afgán frakcióval és a nemzetközi közösség elvárásaival. Ezeket a félelmeket nagymértékben táplálja a tálib propaganda, amelyben gyakran elhangzik, hogy vereséget mértek az Amerikai Egyesült Államokra, és az Iszlám Emirátus visszaállítása a céljuk. ${ }^{40}$ Mindenesetre a Trump-adminisztráció végéhez közeledve az afgánközi tárgyalások csak lassan haladtak előre, míg a tálib erőszak és a fegyveres támadások továbbra is az afgán mindennapok részét képezték. A tálibok és a kabuli kormányzati delegációk december 2-án adták hírül, hogy aláírtak egy háromoldalas megállapodást a tárgyalások szabályairól és azok folyamatáról, amit az egyre türelmetlenebb nemzetközi közösség visszafogott lelkesedéssel ugyan, de

\footnotetext{
${ }^{40}$ Lásd James B. Cunningham 2019. szeptember 19-i képviselöházi külügyi bizottsági meghallgatása. 19. 09. 2019. https://docs.house.gov/meetings/FA/FA00/20190919/109992/HHRG-116-FA00-Wstate-CunninghamJ-20190919. pdf (Letöltés időpontja: 2020. 10. 08.)
} 
egyfajta áttörésként értékelt. ${ }^{41}$ A lassú és körülményes egyeztetések tükrében nehéz nem felfedezni a tálibok kivárásos taktikáját, hiszen semmi nem sürgeti őket a kabuli kormányzattal való megállapodásban. Legalábbis nem egy olyanban, amelyet a kabuli kormány a nemzetközi katonai jelenlét támogatását a háta mögött tudva kötne meg. Az a jövő kérdése lesz, hogy a tálib vezetők külső nyomás nélkül is belátják-e, hogy a különbözö etnikumok és hatalmi centrumok érdekeit méltányosan figyelembe vevő belső kiegyezésre van szükség Afganisztánban, vagy folytatódik az erőszakspirál. Az ország utolsó fél évszázados története sajnos e tekintetben keserü tanulsággal szolgál.

\section{ÖSSZEGZÉS}

Donald Trump elnökségének Afganisztán-politikája két jól elhatárolható szakaszra osztható. Az első a hivatalba lépésétől 2018 nyaráig tartott, ezalatt egy olyan stratégia határozta meg Washington lépéseit, amely főbb elemeiben a korábbi amerikai stratégiák egyes elemeivel mutatott nagyfokú hasonlóságot. A hangsúly a katonai nyomásgyakorláson volt, amely a tálib ellenállás erővel való megtörését célozta. Ennek eredménytelensége, a Washington álláspontjában bekövetkezett fordulat, valamint a tálibok tárgyalási készsége nyitották meg az Afganisztán-politika második szakaszát, amely a tárgyalásos rendezésre és a kivonulás elökészítésére irányult. A 2018 közepétől datálható új megközelítés a gyakorlatban szakítás volt a 2017-es stratégiával, és Washington jelentős engedményeket tett annak érdekében, hogy a tárgyalások elmozduljanak a holtpontról. A tálibok cserébe kevés, leginkább ígéretekben kimerülő vállalást tettek, miközben továbbra is hevesen támadták a kabuli kormányszerveket.

Washington új megközelítését, vagy inkább - ha figyelembe vesszük a Trump döntésmódjáról szóló bennfentes információkat - az elnök fordulatát nevezhetjük pragmatikusnak, amennyiben kész volt változtatni korábbi stratégiáján és az elörelépés érdekében komoly politikai engedményeket tenni a táliboknak. Másfelől viszont éppen az Amerikai Egyesült Államok további elkötelezettségét kérdőjelezte meg azzal, hogy az afgánközi tárgyalások dinamikájától függetlenül, a feltételesség elvével szakítva és belpolitikai megfontolásoktól vezérelve, továbbá a szövetségesekkel való egyeztetés nélkül erőltette az amerikai katonai jelenlét további csökkentését.

Trump egy törékeny afgánközi békefolyamatot, minimális amerikai katonai jelenlétet, a teljes csapatkivonásra vonatkozó, 2021. április 30-i határidejü kötelezettségvállalást, valamint bizonytalanságban tartott szövetségeseket hagyott utódjára. Joe Biden, az új elnök választása nagymértékben leegyszerüsödött: vagy eleget tesz az előző kormányzat által tett vállalásnak, és kivonja az amerikai erőket annak minden következményével, vagy a maradás mellett dönt és újra megerősíti az Amerikai Egyesült Államok afganisztáni jelenlétét azzal, hogy kedvezőbb feltételeket próbál teremteni a háború befejezésére. Biden korábbi állásfoglalásainak tükrében nem volt meglepő, hogy - az új elnöki adminisztráció hivatalba lépése által teremtett politikai momentumot is kihasználva - az első opció mellett döntött, és 2021. április 14-én bejelentette, hogy ,ideje véget vetni az örökké tartó

${ }^{41}$ Afghan gov't, Taliban announce breakthrough deal in peace talks. Al-Jazeera, 02. 12. 2020. https://www.aljazeera. com/news/2020/12/2/afghan-govt-taliban-announce-breakthrough-deal-in-peace-talks (Letöltés időpontja: 2020. 12. 05.) 
háborúnak". ${ }^{42}$ A döntés értelmében Washington a 2001. szeptember 11-i terrortámadás huszadik évfordulójáig kivonja az amerikai katonákat Afganisztánból. Ugyanaznap a NATO-tagállamok is egyetértettek abban, hogy május 1-én szintén megkezdik a kivonulást a közép-ázsiai országból. Ezzel ugyan később, mint azt a tálibokkal kötött megállapodás elöírta, de a szövetségesekkel egyeztetve és a távozást velük összehangolva ér véget az Amerikai Egyesült Államok leghosszabb háborúja. Ahhoz azonban nagy valószínűséggel a nemzetközi közösség tartós figyelmére és támogatására lesz szükség, hogy Afganisztán ne süllyedjen ismét a polgárháború kilátástalanságába, és ne váljon a globális terrorizmus melegágyává. A Szovjetunió 1989-es távozását követő évek eseményei intő példaként kell hogy szolgáljanak e tekintetben.

(A kézirat lezárva: 2021. április 15.)

\section{FELHASZNÁLT IRODALOM}

Afghan gov't, Taliban announce breakthrough deal in peace talks. 02. 12. 2020. Al-Jazeera. https://www. aljazeera.com/news/2020/12/2/afghan-govt-taliban-announce-breakthrough-deal-in-peace-talks Afghanistan - Protection of Civilians in Armed Conflict. Annual Report 2018. UNAMA-UNHR, 24. 02. 2019. https://unama.unmissions.org/sites/default/files/afghanistan_protection_of_civilians_ annual_report2018_final_24_feb_2019_0.pdf

Afghanistan war: Taliban tell Trump their „doors are open”. BBC News, 17. 09. 2019. https://www. bbc.com/news/world-asia-49729612

Agreement for Bringing Peace to Afghanistan between the Islamic Emirate of Afghanistan which is not recognized by the United States as a state and is known as the Taliban and the United States of America. 29. 02. 2020. https://www.state.gov/wp-content/uploads/2020/02/Agreement-ForBringing-Peace-to-Afghanistan-02.29.20.pdf

Biden, Joseph R., Jr.: Why America Must Lead Again. Rescuing U.S. Foreign Policy After Trump. Foreign Affairs, 03./04. 2020. https://www.foreignaffairs.com/articles/united-states/2020-01-23/ why-america-must-lead-again

Bolton, John: The Room Where it Happened. A White House Memoir. Simon\&Schuster, New York, 2020. Burns, Robert - Riechmann, Deb: Afghanistan: The war Trump and Clinton have ignored. AP News, 02. 11. 2016. https://apnews.com/article/1cf16a133b02463fa7c796cb53aa826e

Cooper, Helen - Stolberg, Sheryl Gay: Obama Ponders Outreach to Elements of Taliban. The New York Times, 07. 03. 2009. https://www.nytimes.com/2009/03/08/us/politics/08obama.html

Cunningham, James B. 2019. szeptember 19-i képviselöházi külügyi bizottsági meghallgatása. 19. 09. 2019. https://docs.house.gov/meetings/FA/FA00/20190919/109992/HHRG-116-FA00-WstateCunninghamJ-20190919.pdf

Davis, Julie Hirschfeld - Landler, Mark: Trump Outlines New Afghanistan War Strategy With Few Details. The New York Times, 22. 08. 2017. https://www.nytimes.com/2017/08/21/world/asia/ afghanistan-troops-trump.html

Dobbins, James - Finn, Robert P. - Neumann, Ronald E. - Wood, William - Negroponte, John - Wayne, E. Anthony - Crocker, Ryan - Cunningham, James - Llorens, Hugo: US-Taliban negotiations: How to avoid rushing to failure. Atlantic Council, 03. 09. 2019. https://www.atlanticcouncil.org/ blogs/new-atlanticist/us-taliban-negotiations-how-to-avoid-rushing-to-failure/

\footnotetext{
${ }^{42}$ Remarks by President Biden on the Way Forward in Afghanistan. The White House, 04. 14. 2021. https://www. whitehouse.gov/briefing-room/speeches-remarks/2021/04/14/remarks-by-president-biden-on-the-way-forwardin-afghanistan/ (Letöltés időpontja: 2021. 04. 14.)
} 
Gibbons-Neff, Thomas: US Announces Troop Withdrawal in Afghanistan as Respite From Violence Ends. The New York Times, 02. 03. 2020. https://www.nytimes.com/2020/03/02/world/asia/ustroop-withdrawal-afghanistan.html

Graham, Lindsey - Keane, Jack: We can't outsource our security to anyone - especially the Taliban. The Washington Post, 28. 08. 2019. https:/www.washingtonpost.com/opinions/2019/08/28/afghanwar-must-end-our-terms-not-talibans/

Hearing to Receive Testimony on the Department of Defense Budget Posture in Review of the Defense Authorization Request for Fiscal Year 2018 and the Future Years Defense Program. Stenographic Transcript Before the Committee on Armed Services. United States Senate, Washington D.C., 13. 06. 2017. https://www.armed-services.senate.gov/imo/media/doc/17-58_06-13-17.pdf

Hearing to Receive Testimony on the Situation in Afghanistan. Stenographic Transcript Before the Committee on Armed Services. United States Senate, Washington D.C., 09. 02. 2017. https://www. armed-services.senate.gov/imo/media/doc/17-08_02-09-17.pdf

Hohmann, James: The Daily 202: Trump allies more outraged than Democrats over his Afghanistan pullout. The Washington Post, 18. 11. 2020. https://www.washingtonpost.com/politics/2020/11/18/ daily-202-trump-allies-more-outraged-than-democrats-over-his-afghanistan-pullout/

Hudson, John - Dawsey, Josh: Bolton sidelined from Afghanistan policy as his standing with Trump falters. The Washington Post, 30. 08. 2019. https:/www.washingtonpost.com/world/national-security/ bolton-sidelined-from-afghanistan-policy-as-his-standing-with-trump-falters/2019/08/30/796512568888-483b-9fd1-c47a2cfadab7_story.html

Joint Declaration between the Islamic Republic of Afghanistan and the United States of America for Bringing Peace to Afghanistan. 29. 02. 2020. https://www.state.gov/wp-content/uploads/2020/02/02.29.20US-Afghanistan-Joint-Declaration.pdf

Kermani, Secunder: Afghanistan: Where the road to peace is harder than war. BBC News, 23. 12. 2019. https://www.bbc.com/news/world-asia-50826420

Kheel, Rebecca: Cheney, House Republicans express 'serious concerns' with US-Taliban deal. The Hill, 27. 02. 2020. https://thehill.com/policy/defense/484964-cheney-house-republicans-express-seriousconcerns-with-us-taliban-deal

Leonnig, Carol D. - Rucker, Philip: 'You're a bunch of dopes and babies': Inside Trump's stunning tirade against generals. The Washington Post, 17. 01. 2020. https://www.washingtonpost.com/politics/ youre-a-bunch-of-dopes-and-babies-inside-trumps-stunning-tirade-against-generals/2020/01/16/ d6dbb8a6-387e-11ea-bb7b-265f4554af6d_story.html

Linschoten, Alex Strick van - Kuehn, Felix (eds.): The Taliban Reader. War, Islam and Politics. Hurst and Company, London, 2018.

Mashal, Mujib: U.S. and Taliban Agree in Principle to Peace Framework, Envoy Says. The New York Times, 28. 01. 2019. https://www.nytimes.com/2019/01/28/world/asia/taliban-peace-deal-afghanistan. $\mathrm{html}$

Mashal, Mujib - Schmitt, Eric: White House Orders Direct Taliban Talks to Jump-Start Afghan Negotiations. The New York Times, 15. 07. 2018. https://www.nytimes.com/2018/07/15/world/asia/ afghanistan-taliban-direct-negotiations.html

Miller, Laurel E. 2019. 09. 19-i képviselőházi külügyi bizottsági meghallgatása. https://docs.house.gov/ meetings/FA/FA00/20190919/109992/HHRG-116-FA00-Wstate-MillerL-20190919.pdf

Miller, Laurel E. - Blake, Jonathan S.: Envisioning a Comprehensive Peace Agreement for Afghanistan. RAND Corporation, 2019. https://www.rand.org/content/dam/rand/pubs/research_reports/RR2900/ RR2937/RAND_RR2937.pdf 
Pramuk, Jacob: What Trump said about Afghanistan before he became president. CNBC, 21. 08. 2017. https://www.cnbc.com/2017/08/21/what-trump-said-about-afghanistan-before-he-becamepresident.html

Remarks by President Biden on the Way Forward in Afghanistan. The White House, 04. 14. 2021. https:// www.whitehouse.gov/briefing-room/speeches-remarks/2021/04/14/remarks-by-president-bidenon-the-way-forward-in-afghanistan/

Remarks by President Trump on the Strategy in Afghanistan and South Asia. The White House, 21. 08. 2017. https://www.whitehouse.gov/briefings-statements/remarks-president-trump-strategyafghanistan-south-asia/

Scherer, Michael - Jaffe, Greg - Dawsey, Josh: In private chat with senator, Trump hints at policy shift in Afghanistan. The Washington Post, 30. 04. 2018. https://www.washingtonpost.com/politics/ in-private-chat-with-senator-trump-hints-at-policy-shift-in-afghanistan--and-a-return-toisolationism/2018/04/30/e0e9blec-4995-11e8-827e-190efaflflee_story.html

SIGAR Quarterly Report to the United States Congress. Special Inspector General for Afghanistan Reconstruction, 30. 10. 2018. https://www.sigar.mil/pdf/quarterlyreports/2018-10-30qr.pdf

Starr, Barbara - Browne, Ryan - Gaouette, Nicole: Trump fires Secretary of Defense Mark Esper. CNN, 09. 11. 2020. https://edition.cnn.com/2020/11/09/politics/trump-fires-esper/index.html

Statement by the President on Afghanistan. The White House, 15. 10. 2015. https://obamawhitehouse. archives.gov/the-press-office/2015/10/15/statement-president-afghanistan

The situation in Afghanistan and its implications for international peace and security. Report of the UN Secretary-General. A/71/682-S/2016/1049, United Nations Digital Library, 13. 12. 2016. https:// digitallibrary.un.org/record/851672/files/A_71_682\%26S_2016_1049-EN.pdf

Wagner Péter: A tálibok is fundamentalisták, de nem olyan Amerika-ellenes éllel, mint Irán - inkább a szaúdiakhoz állnak közel. KKI Elemzések, E-2020/52. https://kki.hu/wp-content/uploads/2020/ 05/52_KKI-elemzes_AFG_Wagner_20200527.pdf

Wagner Péter: Az Egyesült Államok és Afganisztán kapcsolata a hidegháború után. In: Háda Béla - Matura Tamás (szerk.): Az Amerikai Egyesült Államok ázsiai kapcsolatai. Dialóg Campus, Budapest, 2020.

Wagner Péter: Donald Trump Afganisztán-stratégiájának kérdőjelei. Bátor vállalások vagy üres igéretek? KKI Elemzések E-2017/20. https://kki.hu/assets/upload/20_KKI-elemzes_USA_Wagner_2017 1019.pdf

Wagner Péter: Terrorhullám Kabulban. Valóban erösödik a Talibán és az Iszlám Állam Afganisztánban? KKI Elemzések E-2018/06. https://kki.hu/assets/upload/06_KKI-elemzes_AFG_Wagner_2018 0206.pdf

Whitlock, Craig: The Afghanistan papers. The Washington Post, 09. 12. 2019. https://www.washington post.com/graphics/2019/investigations/afghanistan-papers/afghanistan-war-confidentialdocuments/ 